\title{
Relation between pica and blood lead in areas of differing lead exposure
}

\author{
J E J GALLACHER, P C ELWOOD, K M PHILliPS, B E DAVIES, AND D T JONES \\ Medical Research Council Epidemiology Unit, Cardiff, Department of Geography, University College of \\ Wales, Aberystwyth, and Clwyd Health Authority, Clwyd
}

SUMMARY Surveys were conducted in four areas in Wales with differing degrees of environmental lead. In two areas the source of the lead was traffic and in one it was spoil from lead mining in the past. The fourth area, which served as a control, was a village remote from heavy traffic, industry, and lead mining. Various environmental samples were taken, and children aged 1-3 years and their mothers were studied. Blood lead concentrations were raised in the lead mining area, and within the areas defined by traffic flow the blood lead concentrations of the mothers showed a gradient. Pica in the children, assessed by a questionnaire, showed no relation with blood lead, but the amount of lead removed from the children's hands with 'wet wipes' was an important contributor to blood lead concentrations.

Pica may be defined as the ingestion of alien, non-food substances. It may occur either through deliberate ingestion or through the mouthing of objects or hands. Pica is common in very young children and it has been suggested in explanations of the higher blood lead concentrations that occur in children compared with adults. In areas with high environmental concentrations of lead pica might lead to a serious increment in the lead intake of young children. The problem of pica has usually been studied in clinical situations, and individual children who present with lead poisoning are often found to have ingested soil, dust, or paint heavily contaminated with lead. ${ }^{1-3}$ More recently epidemiological studies of groups of children have suggested that pica is common in young children but they have not shown any consistent relation between pica and concentrations of lead in the body..$^{4-9}$

We report studies of blood lead concentrations in young children; of pica, assessed by questionnaire; and of hand lead measured by a 'wet wipe' technique. Studies were conducted in two areas close to heavy traffic, in one of which old lead mining activity had led to a very high environmental levels of lead, ${ }^{10} 11$ and in a control area remote from traffic and contamination by lead mining.

\section{Method}

The busiest roads in South Wales, excluding the urban area of Cardiff and the M4 motorway, are the main ' $A$ ' roads through the South Wales valleys. These carry traffic in excess of 12000 vehicles a day. Stretches of these roads about three miles long were defined in three of the valleys, and all the houses on the roadside - that is, with no garden or waste area between them and the pavement-were identified. Similar houses in culs de sac off these roads, with no through traffic, were identified. Traffic flow estimates were not available for the culs de sac but were likely to be very low indeed. To match for social class, only similar houses in these culs de sac were identified-namely, houses with no front gardens. A preliminary survey of all these dwellings was conducted to identify all children aged 1-3 years inclusive. These children and their mothers formed two of the population samples studied: one of subjects living very close to heavy traffic and the other of subjects who lived some distance (50$250 \mathrm{~m}$ ) from heavy traffic.

A further population sample was drawn from an area very heavily contaminated by spoil from lead mining in the past with soil lead concentrations up to $48 \mu \mathrm{mol}(10000 \mu \mathrm{g}) / \mathrm{g}$. A census was conducted, and all children aged 1-3 years and their mothers were identified.

The control population consisted of all children aged 1-3 years and their mothers in a village in North Wales remote from industry, heavy traffic, and lead mining. Traffic flow estimates for the former lead mining area and the village were both very low, around 500 vehicles a day. 
A number of environmental samples were taken for estimations of lead content. Air samplers (4.5 $1 / \mathrm{min}$ ) were placed in the kitchens or living rooms of representative dwellings in each area and run for 7 days. Soil samples (about $1 \mathrm{~kg}$ ) were taken from the top $15 \mathrm{~cm}$ of the gardens of all the dwellings in the lead mining area and in the control village. Samples of pavement dust were taken from outside all the houses on the roadside and in the culs de sac. Samples of house dust were taken from the household vacuum cleaners in all the dwellings in all four areas. Samples of water were also taken from the cold tap in the kitchen of every dwelling, but, as almost all the samples had lead concentrations around the limit of detection $(0.005 \mathrm{nmol} / \mathbf{1}(0.001$ $\mu \mathrm{gl} / \mathrm{l})$ ) and as there were no differences in the geometric mean water lead concentrations between the four areas, the lead content of water was not considered further.

Data on pica were obtained by self administered questionnaires completed by the mothers. Each was asked to indicate whether her child 'occasionally', 'frequently', or 'almost all the time' ate soil or dirt, mouthed toys and other objects, or sucked hands and fingers. The items for the pica questionnaire were derived from work by Baltrop et al who studied lead concentrations in children displaying behaviour of these kinds. ${ }^{7}$

Lead on hands was measured by a method devised by Vostal et al. ${ }^{13-15}$ Each mother was given three 'wet wipes' (paper towels soaked in an alcohol based cleansing solution). She was asked to clean her own hands thoroughly with a wet wipe at the end of a normal day and then seal the wet wipe in a plastic bag. She was then asked to clean the hands of her child thoroughly with another wet wipe paying particular attention to the nails, and seal this in another bag. The third wet wipe was used to wipe down the food preparation surfaces in the kitchen.

Capillary blood samples were then taken from the children and venous samples from the mothers. In an independent investigation the accuracy of capillary sampling was evaluated: venous samples were taken from a random half of a population sample of 60 children and capillary samples from the others; the coefficients of variation were $44 \%$ for the venous and $39 \%$ for the capillary samples indicating that contamination of capillary samples was trivial. The mean concentration in the capillary samples, however, was $37 \%$ higher than that in the venous samples, probably owing to haemoconcentration of capillary blood.

Mixed batches of samples from all the areas were submitted to the laboratories and lead concentrations were estimated without knowledge of the area from which they had come. The soil and dust samples were dried, lightly ground, and sieved with a nylon mesh of aperture $2 \mathrm{~mm}$. Lead content was estimated, after extraction with hot concentrated nitric acid, by atomic absorption spectrophotometry with flameless electrothermal excitation. Because of considerable skewness in the lead values of samples from all the environmental sources log transformation was used.

The reproducibility of estimate of lead value in each environmental source was examined by repeating the collection of samples after an interval of about two months. The coefficient of variation $(\mathrm{SD} /$ mean $\times 100 \%)$, based on the duplicate pairs and after logarithmic transformation, was $9 \%$ for pavement dust ( 22 dwellings) and $10 \%$ for house dust ( 25 dwellings). The coefficient of variation of child hand lead using the 'wet wipe' technique was $19 \%$ (based on 17 children). The coefficient of variation of blood lead estimation, based on blind duplicate samples of venous blood, was around $7 \%$.

\section{Results}

Table 1 gives details of the population samples, and Table 2 presents the environmental and blood lead concentrations found. There was an appreciable gradient in indoor air lead values with the highest (mean $\left.0.87 \mathrm{nmol}(0.18 \mu \mathrm{g}) / \mathrm{m}^{3}\right)$ in the area with the most traffic. The dwellings in the former lead mining area had very high soil lead values, and house dust lead values that were considerably higher than in any other area. On the other hand, the dwellings on the roadside had house dust lead values that were only slightly higher than the control village or the

Table 1 Population samples studied

\begin{tabular}{|c|c|c|c|c|c|}
\hline & \multirow{2}{*}{$\begin{array}{l}\text { Total } \\
\text { available }\end{array}$} & \multicolumn{4}{|c|}{ Number $(\%)$ cooperated } \\
\hline & & $\begin{array}{l}\text { Blood } \\
\text { sample }\end{array}$ & Pica & $Q$ & 'Wet wipes' \\
\hline \multicolumn{6}{|c|}{ Roadside dwellings: } \\
\hline Children & 42 & 42 & \multirow{2}{*}{\multicolumn{2}{|c|}{41}} & \multirow{2}{*}{33} \\
\hline Mothers & 42 & 42 & & & \\
\hline \multicolumn{6}{|c|}{ Culs de sac dwellings: } \\
\hline Children & 35 & 30 & \multirow{2}{*}{\multicolumn{2}{|c|}{24}} & \multirow{2}{*}{23} \\
\hline Mothers & 35 & 30 & & & \\
\hline \multicolumn{6}{|c|}{ Old mining area: } \\
\hline Children & 67 & 61 & \multirow{2}{*}{\multicolumn{2}{|c|}{56}} & \multirow{2}{*}{36} \\
\hline Mothers & 67 & 58 & & & \\
\hline \multicolumn{6}{|c|}{ Control village: } \\
\hline Children & 37 & 32 & \multirow{2}{*}{\multicolumn{2}{|c|}{33}} & \multirow{2}{*}{24} \\
\hline Mothers & 37 & 33 & & & \\
\hline \multicolumn{6}{|l|}{ All areas: } \\
\hline Children & 181 & $165(91)$ & \multirow{2}{*}{\multicolumn{2}{|c|}{$154(85)$}} & \multirow{2}{*}{$116(64)$} \\
\hline Mothers & 181 & $163(90)$ & & & \\
\hline
\end{tabular}


Table 2 Lead values in environmental sources. Figures are geometric means and ranges are $95 \%$ confidence limits obtained after log transformation

\begin{tabular}{|c|c|c|c|c|}
\hline & $\begin{array}{l}\text { Indoor } \\
\text { air* } \\
\left(\mathrm{nmol} / \mathrm{m}^{3}\right)\end{array}$ & $\begin{array}{l}\text { Soil } \\
\text { ( } \mu \mathrm{mol})\end{array}$ & 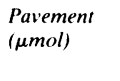 & 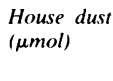 \\
\hline Roadside dwellings $(n=42)$ & $\left\{\begin{array}{l}0 \cdot 87 \\
(0 \cdot 24-2 \cdot 94)\end{array}\right.$ & & $\begin{array}{l}1 \cdot 71 \\
(0 \cdot 83-3 \cdot 52)\end{array}$ & $\begin{array}{l}0.97 \\
(0.24-3.9)\end{array}$ \\
\hline Culs de sac dwellings $(n=30)$ & $\left\{\begin{array}{l}0 \cdot 58 \\
(0 \cdot 14-1 \cdot 78)\end{array}\right.$ & & $\begin{array}{l}1 \cdot 3 \\
(0 \cdot 4-4 \cdot 2)\end{array}$ & $\begin{array}{l}0 \cdot 85 \\
(0 \cdot 19-3 \cdot 8)\end{array}$ \\
\hline Dwellings in old mining area $(n=62)$ & $\left\{\begin{array}{l}0 \cdot 33 \\
(0 \cdot 19-1 \cdot 01)\end{array}\right.$ & $\begin{array}{l}5 \cdot 6 \\
(0 \cdot 7-49)\end{array}$ & & $\begin{array}{l}1 \cdot 68 \\
(0 \cdot 28-10 \cdot 2)\end{array}$ \\
\hline \multirow[t]{2}{*}{ Dwellings in control village $(n=33)$} & $\left\{\begin{array}{l}0 \cdot 19 \\
(0.05-0 \cdot 63)\end{array}\right.$ & $\begin{array}{l}0 \cdot 38 \\
(0 \cdot 1-1 \cdot 4)\end{array}$ & & $\begin{array}{l}0 \cdot 85 \\
(0 \cdot 17-4 \cdot 1)\end{array}$ \\
\hline & $\mathrm{P}<0.001$ & $\mathrm{P}<0 \cdot 001$ & $\mathrm{P}<0 \cdot 05$ & $\mathrm{P}<0.001$ \\
\hline
\end{tabular}

* Indoor air lead values were measured in $14,14,12$, and 9 dwellings respectively: because of the small numbers the ranges given for indoor air lead are minima and maxima.

Conversion: SI to traditional units-lead $1 \mu \mathrm{mol} \approx 207 \mu \mathrm{g}$.

dwellings in the culs de sac. This is perhaps surprising because the lead values on the pavements outside the roadside houses were higher than outside the culs de sac dwellings. Moreover, the amount of dust/unit area outside the roadside dwellings (that is taking account of the weight of dust/unit area) was over three times that outside the culs de sac dwellings, producing mean total lead values of $41 \mu \mathrm{mol}(8.5 \mathrm{mg} /) \mathrm{m}^{2}$ outside the roadside dwellings and $13 \mu \mathrm{mol}(2.7 \mathrm{mg}) / \mathrm{m}^{2}$ outside the culs de sac dwellings.

Table 3 gives the blood lead concentrations in the various population samples. In both the children and their mothers the area that differed most from the control village was the former mining area. In children the excess in mean blood lead concentration was about $30 \%(\mathrm{P}<0.05)$ and in mothers it was about $50 \%(\mathrm{P}<0 \cdot 001)$. The only other significant difference from the control village was in the mothers in the roadside dwellings $(P<0.05)$,

Table 3 Mean (SD) blood lead concentrations in various population samples

\begin{tabular}{ll}
\hline & $\begin{array}{l}\text { Mean }(S D) \text { blood lead } \\
(\mu \text { molll })\end{array}$ \\
\hline Children in dwellings in: & $0 \cdot 80(0 \cdot 41)$ \\
Roadside $(\mathrm{n}=42)$ & $0 \cdot 71(0 \cdot 18)$ \\
Culs de sac $(\mathrm{n}=30)$ & $1 \cdot 09(0 \cdot 43)$ \\
Old mining area $(\mathrm{n}=61)$ & $0 \cdot 85(0 \cdot 42)$ \\
Control village $(\mathrm{n}=32)$ & \\
Mothers in dwellings in: & $0 \cdot 43(0 \cdot 12)$ \\
Roadside $(\mathrm{n}=42)$ & $0 \cdot 43(0 \cdot 14)$ \\
Culs de sac $(\mathrm{n}=30)$ & $0 \cdot 57(0 \cdot 23)$ \\
Old mining area $(\mathrm{n}=58)$ & $0 \cdot 38(0 \cdot 09)$ \\
Control village $(\mathrm{n}=33)$ & \\
\hline
\end{tabular}

Conversion: SI to traditional units-lead $1 \mu \mathrm{mol} / \mathrm{l} \approx 20 \mu \mathrm{g} / 100 \mathrm{ml}$. although the excess in mean blood lead concentration was only about $13 \%$.

The relevance of pica and related activities was then examined. The data obtained by questionnaire showed no consistent association within any area, or within all areas combined, between incidence of pica and the mean blood lead concentration. Table 4 summarises the results of the wet wipe study. Within the roadside dwellings, the culs de sac dwellings, and the control village the means from all three sources-namely, mothers' hands, children's hands, and kitchen surfaces-were remarkably similar. On the other hand, in the old lead mining area there was an excess for each of the sources compared with the control area of about $40 \%$ for the lead on the mothers' hands, $45 \%$ for the lead on the children's hands, and $35 \%$ for lead on the food preparation surfaces. Only the difference for the children's hands, however, was significant $(P<0 \cdot 05)$.

The wet wipe data for the children were examined further by correlation. Because of the significant differences between blood lead concentrations and hand lead concentrations, the data for the old lead

Table 4 Mean (95\% confidence limits) 'wet wipe' lead $(\mu g)$ obtained after transformation to logarithms

\begin{tabular}{|c|c|c|c|}
\hline & $\begin{array}{l}\text { Mothers' } \\
\text { hands }\end{array}$ & $\begin{array}{l}\text { Children's } \\
\text { hands }\end{array}$ & $\begin{array}{l}\text { Kitchen } \\
\text { surfaces }\end{array}$ \\
\hline Roadside dwellings $(\mathrm{n}=33$ ) & $\begin{array}{l}11 \cdot 5 \\
(2-61)\end{array}$ & $\begin{array}{l}15 \cdot 1 \\
(5-47)\end{array}$ & $\begin{array}{l}11 \cdot 0 \\
(2-76)\end{array}$ \\
\hline Culs de sac dwellings $(n=23)$ & $\begin{array}{l}11 \cdot 0 \\
(2-58)\end{array}$ & $\begin{array}{l}12 \cdot 9 \\
(3-60)\end{array}$ & $\begin{array}{c}9 \cdot 6 \\
(1-70)\end{array}$ \\
\hline Old lead mining area $(n=36)$ & $\begin{array}{l}13 \cdot 2 \\
(3-67)\end{array}$ & $\begin{array}{l}20 \cdot 4 \\
(5-87)\end{array}$ & $\begin{array}{l}13 \cdot 5 \\
(3-69)\end{array}$ \\
\hline Control village $(n=24)$ & $\begin{array}{l}9 \cdot 6 \\
(2-53)\end{array}$ & $\begin{array}{l}14 \cdot 1 \\
(6-32)\end{array}$ & $\begin{array}{l}10 \cdot 0 \\
(2-42)\end{array}$ \\
\hline
\end{tabular}


Table 5 Correlation coefficients (' $r$ ') between the blood lead concentrations of mothers and of children and the amounts of lead removed by wet wipes from their hands and from the surface for food preparation in their kitchens

\begin{tabular}{|c|c|c|c|c|}
\hline & \multicolumn{2}{|c|}{ Mother's blood lead } & \multicolumn{2}{|c|}{ Child's blood lead } \\
\hline & $\begin{array}{l}\text { Mother's } \\
\text { hands }\end{array}$ & $\begin{array}{l}\text { Kitchen } \\
\text { surface }\end{array}$ & $\begin{array}{l}\text { Child's } \\
\text { hands }\end{array}$ & $\begin{array}{l}\text { Kitchen } \\
\text { surface }\end{array}$ \\
\hline $\begin{array}{l}\text { Old lead mining area } \\
(n=35)\end{array}$ & 0.05 & $0 \cdot 04$ & $0 \cdot 38^{*}$ & 0.11 \\
\hline $\begin{array}{l}\text { All other areas } \\
(n=79)\end{array}$ & 0.04 & -0.06 & $0 \cdot 08$ & $0 \cdot 26^{*}$ \\
\hline
\end{tabular}

Table 6 Mean (95\% confidence limits) 'wet wipe' lead (nmol) by social class excluding subjects in the old lead mining area

\begin{tabular}{|c|c|c|c|}
\hline & \multicolumn{3}{|l|}{ Social class } \\
\hline & $\begin{array}{l}I+I I \\
(n=15)\end{array}$ & $\begin{array}{l}I I I \\
(n=45)\end{array}$ & $\begin{array}{l}I V+V \\
(n=17)\end{array}$ \\
\hline Mother's hands & $\left\{\begin{array}{l}44.9 \\
(9.7-285)\end{array}\right.$ & $\begin{array}{l}49 \\
(9 \cdot 7-241)\end{array}$ & $\begin{array}{l}73 \\
(14 \cdot 5-372)\end{array}$ \\
\hline Child's hands & $\left\{\begin{array}{l}67 \\
(24-198)\end{array}\right.$ & $\begin{array}{l}73 \\
(24-236)\end{array}$ & $\begin{array}{l}62 \\
(14 \cdot 5-241)\end{array}$ \\
\hline $\begin{array}{l}\text { Food preparation } \\
\text { surface }\end{array}$ & $\left\{\begin{array}{l}40 \\
(9 \cdot 7-140)\end{array}\right.$ & $\begin{array}{l}47 \\
(4 \cdot 8-362)\end{array}$ & $\begin{array}{l}64 \\
(14 \cdot 5-309)\end{array}$ \\
\hline
\end{tabular}

Conversion: SI to traditional units-lead $1 \mathrm{nmol}=0 \cdot 2 \mu \mathrm{g}$.

mining area were examined separately, but the data for the other areas were pooled. Table 5 confirms that in the most heavily contaminated area hand lead correlated significantly with blood lead concentrations. The other correlation that reached statistical significance was between blood lead in children and lead on the food preparation surface in the control area. Multiple regression analyses confirmed these general findings in that within the lead contaminated area the amount of lead removed by the wet wipes from children's hands was the only significant contributor to the children's blood lead concentrations.

We finally analysed the association between the wet wipe lead results and social class, based on the occupation of the head of each household (Table 6). Evidence suggested a trend towards higher mean lead values with lower social classes in the data for mothers' hands and the food preparation surfaces, but none of the differences was statistically significant.

\section{Discussion}

The measurement of pica is difficult. ${ }^{12}$ Questionnaire methods of measurement have not always shown a relation with blood lead concentrations. For example, in similar studies Needleman reported a positive relation between pica and lead in teeth ${ }^{8}$ but Winnecke reported no such relation. ${ }^{9}$ Certainly no evidence has been produced showing the validity and repeatability of pica questionnaires. The wet wipe method may be relatively crude but it is surprisingly reproducible with a coefficient of variation of around $19 \%$. Furthermore, it has been reported in other studies to discriminate between children with differing lead exposure. ${ }^{13-15}$

The effect of pica on body lead concentrations in areas contaminated by lead from the petrol has been variously estimated. Vostal et al measured the lead on children's hands and found $97 \mathrm{nmol}(20 \mu \mathrm{g})$ in an urban area but only $24 \mathrm{nmol}(5 \mu \mathrm{g})$ on the hands of suburban children. ${ }^{13}$ Duggan and Williams estimated a daily dust lead intake in urban children of $241 \mathrm{nmol}(50 \mu \mathrm{g}){ }^{16}$ Day et al estimated that for urban children betweeen 24 (5) and $241 \mathrm{nmol}$ (50 $\mu \mathrm{g}$ ) of lead can transfer to sticky sweets from hands and so be ingested during half an hour of play. ${ }^{17}$ Stephens estimated that up to $27 \%$ of an urban child's daily lead intake comes from petrol lead deposited on their hands. ${ }^{18}$ With estimates such as these one would expect clear differences to be shown in both environmental and blood lead values between the areas of different traffic density in this study, however, all but the first of these necessitate so many assumptions that they are of little value.

The pattern of lead values in the various environmental sources studied (Table 2) suggests that there is a considerable attenuation between the source and the subject. Thus, although soil lead values in the lead mining area were very high, house dust concentrations were only about twice those in the control village. Furthermore, in the three areas defined by traffic flow, indoor air lead concentrations showed considerable differences (and outdoor roadside air concentrations would have probably shown even greater differences) yet house dust concentrations did not differ significantly. House dust is probably one of the most important environmental sources of lead for children ${ }^{13}$ and certainly the most important source relevant to pica. It is therefore not surprising that hand lead values, which seem a more reliable measure than answers to a questionnaire on pica, show no significant differences between the three areas defined by traffic flows, and that there is an excess of hand lead in residents in the former lead mining area that has higher house dust lead values. Furthermore, the blood lead concentrations follow this same pattern, suggesting that pica and related behaviours are relevant to blood lead concentrations in young children. 
Only Barltrop et al have examined the effect of pica in an area of high concentration of soil with lead, ${ }^{19}$ although all other studies on pica have been conducted in areas of current industrial activity that also have high levels of lead in soil. ${ }^{20-23}$ They reported, for an area with high soil lead values (over $48.31 \mu \mathrm{mol}(10000 \mu \mathrm{g}) / \mathrm{g})$, an increase in blood lead concentration of only $9 \%$ for children showing pica compared with children not showing pica.

One of the unexpected findings in our work was the raised blood lead concentrations in mothers in the old mining area as well as in their children. This may well relate to the higher hand lead values they showed and the greater amounts of lead removed by wet wipes from the food preparation surfaces. These data suggest, therefore, that in areas of high environmental lead a reduction in blood lead concentration is likely, both in children and in adults, with improved standards of personal and domestic hygiene.

We are grateful to C Toothill of the Supraregional Assay Service Lead Laboratory in Leeds for the blood lead analyses.

\section{References}

${ }^{1}$ Burrows NFE, Rendle-Short J, Hannah D. Lead poisoning in children. Br Med J 1951;i:329-34.

2 Chisholm JJ, Harrison HE. The exposure of children to lead. Pediatrics 1956;18:943-57.

${ }^{3}$ Greenberg M, Jacobzinen H, McLaughlin MC, Fuerst HT, Pelliteri O. A study of pica in relation to lead poisoning. Pediatrics 1958;22:756-60.

${ }^{4}$ Millican FK, Layman EM, Lourie RS, Takahashi LY, Dublin CC. The prevalence of ingestion and mouthing of non-edible substances by children. Clinical proceedings of the Children's Hospital (Washington) 1962;28:207-14.

5 Barltrop D. The prevalence of pica. Am J Dis Child 1966;112:116-23.

6 Barltrop D, Killala NJP. Faecal excretion of lead by children. Lancet 1967;ii:1017-9.

${ }^{7}$ Barltrop D, Strehlow CD, Thornton I, Webb JS. Significance of high soil lead concentrations for childhood lead burdens: Environ Health Perspect 1974;7:75-82.
${ }^{8}$ Needleman HL, Gunnoe C, Leviton R, et al. Deficit in psychologic and classroom performance of children with elevated dentine lead levels. $N$ Engl J Med 1979;300:689-95.

${ }^{9}$ Winnecke G, Harding KG, Brockhaus A. Neuropsychological studies in children with elevated tooth lead concentrations. Int Arch Occup Environ Health 1983;51:231-52.

${ }^{10}$ Davies BE, Roberts LJ. Heavy metals in soil and radish in a mineralised limestone area of Wales, Great Britain. Sci Total Environ 1975;14:249-61.

$"$ Medical Research Council. Plwm yng Nghymru: lead in Wales. London: MRC Epidemiology Unit, 1983.

12 DHSS. Lead and health. Report of the DHSS Working Party on lead in the environment. London: HMSO, 1980.

13 Vostal JJ, Taves E, Sayre JW, Charney E. Lead analysis of house dust: a method for the detection of another source of lead exposure in inner city children. Environ Health Perspect 1974;7:91-7.

${ }^{14}$ Sayre JW, Charney E, Vostal JJ. Pless IB. House and hand dust as a potential source of childhood lead exposure. Am J Dis Child 1974;127:167-70.

15 Charney E, Sayre J, Coulter M. Increased lead absorption in inner city children: where does the lead come from? Pediatrics 1980;65:226-31.

16 Duggan M, Williams S. Lead-in-dust in city streets. Sci Total Environ 1977;7:91-7.

17 Day JP, Hart M, Robinson MS. Lead in urban street dust. Nature 1975;253:343-5.

${ }^{18}$ Stephens R. Human exposure to lead from motor vehicle emmissions. International Journal of Environmental Studies 1981;17:73-83.

19 Barltrop D, Strehlow CD, Thornton I, Webb JS. Absorption of lead from dust and soil. Postgrad Med J 1975;51:801-4.

${ }^{20}$ Landrigan PJ, Baker EL, Feldman MD, et al. Increased lead absorption with anemia and slowed nerve conduction in children near a lead smelter. J Pediatr 1976;89:904-10.

21 Yankel AJ, Lindern Von IH, Walter SD. The Silver Valley lead study: the relationship between childhood blood levels and environmental exposure. J Air Pollut Control Assoc 1977;27:763-7.

22 Roels HA, Buchet JP, Lauwerys RR, et al. Exposure to lead by the oral and the pulmonary routes of children living in the vicinity of a primary lead smelter. Environ Res 1980;22:81-94.

23 Roberts TM, Gizyn W, Hutchinson TC. Lead contamination of air, soil, vegetation and people in the vicinity of secondary lead smelters. Eighth annual conference on trace substances in environmental health. University of Missouri, 1974:155-66.

Correspondence to Mr J Gallacher, MRC Epidemiology Unit, 4 Richmond Road, Cardiff CF2 3AS.

Received 3 October 1983 